2018

\title{
Independence is the New Health
}

Laura D. Hermer

Mitchell Hamline School of Law, laura.hermer@mitchellhamline.edu

Publication Information

12 Saint Louis University Journal of Health Law \& Policy 5 (2018)

Reprinted with permission of the Saint Louis University Journal of Health Law \& Policy (C2018 St. Louis University School of Law, St. Louis, Missouri

\section{Repository Citation}

Hermer, Laura D., "Independence is the New Health" (2018). Faculty Scholarship. 462.

https://open.mitchellhamline.edu/facsch/462

This Article is brought to you for free and open access by Mitchell Hamline 


\title{
Independence is the New Health
}

\begin{abstract}
Medicaid plays key roles in supporting our nation's health. Under the Affordable Care Act, Medicaid took an even more central position in public health endeavors by extending coverage in all interested states to millions of adults who typically fell through the health care cracks. Nevertheless, the Trump administration is now undoing these gains by actively encouraging states to curtail access to Medicaid in key respects while using the rhetoric of health.

This article examines Trump administration efforts in two contexts: (1) state $\$ 1115$ waiver applications seeking to better align their Medicaid programs with cash welfare and food stamp programs, and (2) changes to Medicaid funding for contraceptive and other reproductive health services. It concludes that, to better protect Medicaid and strengthen public support for it, it may make more sense to focus not on granular medical outcomes when evaluating Medicaid's success, but rather on the larger role it plays in supporting beneficiaries' lives. The Trump administration is right that independence is healthy. However, it is difficult to be independent if one lacks health, or faces financial ruin if one needs healthcare, or has unreasonable or nonexistent family planning and reproductive health choices. Evidence suggests that stable, secure access to coverage via Medicaid, as one piece of our safety net, makes beneficiaries feel more emotionally and financially secure and provides them improved access to needed services. As such, if Medicaid were allowed to remain both expansive and stable, we may reasonably expect gradually to see more stability in communities supported by Medicaid and other social supports, and more freedom of opportunity for beneficiaries and their families. Such a strategy would call the Trump administration on its own rhetoric while providing working-class Trump supporters, among many others, with means to help attain their desired ends.
\end{abstract}

\section{Keywords}

Medicaid, Medical care

\section{Disciplines}

Health Law and Policy | Social Welfare Law 


\title{
INDEPENDENCE IS THE NEW HEALTH
}

\author{
LAURA D. HERMER *
}

\begin{abstract}
Medicaid plays key roles in supporting our nation's health. Under the Affordable Care Act, Medicaid took an even more central position in public health endeavors by extending coverage in all interested states to millions of adults who typically fell through the health care cracks. Nevertheless, the Trump administration is now undoing these gains by actively encouraging states to curtail access to Medicaid in key respects while using the rhetoric of health.

This article examines Trump administration efforts in two contexts: (1) state $\$ 1115$ waiver applications seeking to better align their Medicaid programs with cash welfare and food stamp programs, and (2) changes to Medicaid funding for contraceptive and other reproductive health services. In the process, it concludes that, when ideology trumps public health, it not only leads to bad health outcomes, but also, potentially, to bad legal outcomes. Those who value Medicaid as a strong safety net and public health program need to alter their rhetoric in seeking to protect and bolster it by focusing on Medicaid's role in supporting individuals and communities. Independence is healthy, and Medicaid can play a key role in supporting our independence when we all accept and support its role as a robust safety net program on which all Americans should be able to rely if necessary.
\end{abstract}

\footnotetext{
* Professor, Mitchell Hamline School of Law, Saint Paul, Minnesota. This article is based on a presentation delivered at Saint Louis University School of Law's 30th Annual Health Law Symposium.
} 


\section{INTRODUCTION}

Medicaid plays key roles in supporting our nation's health, from facilitating access to preventive and public health services like vaccinations, smoking cessation, addiction treatment, and reproductive health services for working class and other low-income adults, to giving states financial and policy tools to improve care delivery to low-income populations. ${ }^{1}$ Under the Affordable Care Act (ACA), Medicaid took an even more central position in these endeavors by extending coverage in all interested states to millions of adults who typically fell through the health care cracks. ${ }^{2}$ As a result of the ACA's Medicaid expansion, approximately fifteen million U.S. residents have obtained reliable coverage. ${ }^{3}$ This has unsurprisingly yielded real and positive results for beneficiaries. ${ }^{4}$

Nevertheless, the Trump administration has actively encouraged states to curtail access to Medicaid in key respects by using the rhetoric of health. For example, the Centers for Medicare and Medicaid Services (CMS) claims that imposing work requirements on certain Medicaid beneficiaries might improve beneficiary health by promoting healthy employment behaviors and diminishing reliance on public programs. ${ }^{5}$ Independence is so healthy, according to CMS, that it is worth restricting access to Medicaid in order to push beneficiaries into that condition. ${ }^{6}$

This article will examine such efforts and their results in two contexts: (1) state $\$ 1115$ waiver applications seeking to better align their Medicaid programs with cash welfare and food stamp programs, and (2) changes to Medicaid funding for contraceptive and other reproductive health services. In the process, it will show that when ideology trumps public health, it not only leads to bad outcomes but also demonstrates how quickly the legal edifice on which Medicaid is constructed can become undone when shared policy presumptions can no longer be assumed.

The first section will briefly examine public health programs versus health insurance in promoting health and longevity along with some of the roles that Medicaid plays in advancing public and population health. The second section will then look at two ways that the Trump administration has sought to rein in Medicaid, in one case by appealing to public and population health concepts, and in another case by impacting programs that directly affect public health efforts. In each case, this article will consider the legal ground for the administration's actions, and whether, and to what extent, existing evidence

1. See infra notes $12-18$ and associated text

2. See infra notes 19-21 and associated text.

3. See infra note 22 and associated text.

4. See infra notes $23-25$ and associated text.

5. See infra notes $37-41$ and associated text

6. See CTRS. FOR MEDICARE \& MedicAid SERVs., INDEPENDENT AT HOME DEMONSTRATION FACT SHEET 1 (2019), https://innovation.cms.gov/Files/fact-sheet/iah-fs.pdf. 
supports such efforts. The third section will conclude by suggesting how we might reframe efforts to preserve Medicaid programs and funding.

\section{Medicaid’s Role in Public and Population Health}

While there is debate over the percentages attributable to each, public health measures have arguably made more impact on people's lives and health over the long-term than the provision, or lack thereof, of medical services. Undoubtedly, when people are sick or injured, they need medical care and coverage for that care. Advances in medical care have certainly been responsible, particularly in the last fifty years or so, for real gains in life expectancy. ${ }^{7}$ But most of the time, most people are relatively healthy and have little need for extensive health care. ${ }^{8}$ Arguably, the conditions in which we live - the cleanliness of our air, water, and soil; the wholesomeness and safety of our food; the protection we have against communicable diseases; the habitability of our dwellings; the conduciveness of our living environment to mental health; and our financial and intellectual ability to implement advances in health-enhancing knowledge-have a more persistent and pervasive effect on the quality and length of our lives than coverage typically does. ${ }^{9}$

Public health measures often have little to do with the receipt of medical care: take, for example, ensuring public access to clean drinking water or eliminating lead in consumer products that children might inadvertently ingest. But in some cases, public health and medical or clinical services go hand in hand. In such cases, reliability and breadth of health coverage is key. This is particularly the case with Medicaid, the federal-state program covering health care and services for certain categories of low-income Americans.

Medicaid has long covered diagnosis and treatment for a wide range of communicable diseases, vaccinations for children, certain mental health and substance abuse services, and family planning and other reproductive and

7. See, e.g., David M. Cutler et al., The Value of Medical Spending in the United States: 1960-2000, 355 NEw ENGL. J. MED. 920, 921-23 (2006).

8. See, e.g., Berhanu Alemayehu \& Kenneth E. Warner, The Lifetime Distribution of Health Care Costs, 39 HeAlth SERvs. RES. 627, 636-37 (2004) ("For the average life table member, only a fifth of all lifetime expenditures occurs during the first half of life (79.6 percent of expenditures remaining after age 40 ), while nearly half ( 48.6 percent) accrues after age $65 ")$.

9. See generally Bruce G. Link \& Jo C. Phelan, McKeown and the Idea that Social Conditions Are Fundamental Causes of Disease, 92 AM. J. PUB. HEALTH 730, 730-31 (2002) (arguing that, although direct health-related services are also important, social conditions are fundamental causes of disease and death "because they shape the distribution of the healthenhancing circumstances that health-directed human agency provides"); see also David M. Cutler et al., The Determinants of Mortality, 20 J. ECON. PERSPeCTIVES 97 (2006) (examining the role that different factors such as public health spending, improved nutrition, vaccinations, education, and health care have played in improving morbidity and mortality in different global contexts). 
maternal health services for low-income beneficiaries. ${ }^{10}$ It helps beneficiaries make use of care by providing non-emergency medical transportation, as well as medical coordination and health education services to certain populations. ${ }^{11}$ In some circumstances, states have obtained permission to use Medicaid dollars to provide housing, voluntary job training, and other services to subsets of beneficiaries. ${ }^{12}$

With respect to reproductive and maternal health services, Medicaid has long been a primary source of care for low-income women. Women of reproductive age constitute approximately seventy percent of female Medicaid beneficiaries nationwide. ${ }^{13}$ Family planning is a mandatory Medicaid benefit. ${ }^{14}$ What's more, even in states with a Medicaid managed care waiver, which allows states to limit access to health care providers, Medicaid beneficiaries must be given unfettered access to qualified family planning providers. ${ }^{15}$ This helps ensure that beneficiaries get the services and care they need. Thus, even providers like Planned Parenthood, which has long been under attack by certain anti-abortion politicians, are still included in all state Medicaid plans with family planning programs that are jointly funded by the federal government. ${ }^{16}$

Under the ACA, states must include medically assisted smoking cessation therapies in their state plans. ${ }^{17}$ The ACA also incentivizes states to cover clinical preventive services that have received a grade of either " $A$ " or "B" from the U.S.

10. See DeP'T of Health \& Hum. Servi., Facing Addiction In AMERICA: The Surgeon GENERAL's REPORT ON ALCOHOL, DRUGS, AND HEALTH 6-17, 7-13 (2016); see also Melissa S. Kearney \& Phillip B. Levine, Subsidized Contraception, Fertility, and Sexual Behavior 3-5 (Nat'1 Bureau of Econ. Research, Working Paper No. 13045, 2007). Note that in the mid 1990s states started applying for $\$ 1115$ waivers to expand family planning services to women who do not otherwise qualify for Medicaid (often 185\% FPL). Id. at Table 1; RACHEL BENSON GOLD, STATE EFFORTS TO EXPAND MEDICAID-FundED FAMILY PLANNING SHOW PROMISE 8 (1999)

11. Amelia Myers, Non-Emergency Medical Transportation: A Vital Lifeline for a Healthy Community, NAT'L CONF. ST. LEGISLATURES, http://www.ncsl.org/research/transportation/ non-emergency-medical-transportation-a-vital-lifeline-for-a-healthy-community.aspx\#need (last visited August 9, 2018).

12. Michael Ollove, States Freed to Use Medicaid Money for Housing, PEw, Nov. 20. 2015 at 1, 2; Nat'l CONFERENCE of State Legislatures, Understanding Medicaid Section 1115 WAIVERS: A PRIMER FOR STATE LEGISLATURES 9 (2017), http://www.ncsl.org/Portals/1/ Documents/Health/Medicaid_Waivers_State_31797.pdf.

13. Usha Ranji et al., Medicaid and Family Planning: Background and Implications of the ACA, KAISER FAM. FOUND. 1 (2016), http://files.kff.org/attachment/issue-brief-medicaid-and-fami ly-planning-background-and-implications-of-the-aca.

14. 42 U.S.C. $\$ 1396 \mathrm{~d}(\mathrm{a})(4)(\mathrm{C})(2016)$.

15. See infra note 94 and associated text.

16. Texas's family planning program for women is solely state-funded, so that it does not need to include Planned Parenthood or other providers that perform abortions. See, e.g., Jessie Hellmann, Texas Wants Back Family Planning Funds it Lost Under Obama for Defunding Planned Parenthood, THE HILL (Mar. 23, 2018), http://thehill.com/policy/healthcare/379990-texas-wantsback-family-planning-funds-it-lost-under-obama-for-defunding.

17. 42 U.S.C. $\$ 1396 r-8(d)(7)(A)(2012)$. 
Preventive Services Task Force, as well as adult vaccines recommended by the Advisory Committee on Immunization Practices. ${ }^{18}$ Medicaid expansion states must include mental health and substance abuse treatment among the services available to the expansion population, and must do so at parity with other health benefits. ${ }^{19}$

As a result of the ACA's Medicaid expansion, fifteen million people have obtained coverage, most of whom had no other coverage source beforehand. ${ }^{20}$ Unsurprisingly, this has yielded real and positive results with respect to both receipt of care impacting public health, and the financial stability of relevant providers. Studies have found, for example, that Medicaid coverage of medication-assisted therapy for opioid addiction increased substantially in expansion states-by seventy percent or more. ${ }^{21}$ Preventive care, including HIV screening, increased significantly among Medicaid beneficiaries in expansion states as compared to non-expansion states. ${ }^{22}$ Multiple studies report that the percentage of patients at sexually transmitted disease (STD) clinics with health insurance increased. ${ }^{23}$

The Medicaid expansion's potential for improving health equity and population health is perhaps even greater. Medicaid plays a key role in covering the nation's children and ensuring they have a healthy start. ${ }^{24}$ Evidence shows that kids who receive Medicaid-covered services grow up to be healthier and

18. 42 U.S.C. $\S 1396 d(a)(13)(A) \&$ (B) (2012); 42 U.S.C. $\S 1396 d(b)(2012)$

19. 42 U.S.C. $\$ 1396 u-7(b)(2)(A)(v)(2012)$.

20. See Medicaid Expansion Enrollment, KAISER FAM. FOUND., https://www.kff.org/healthreform/state-indicator/medicaid-expansion-enrollment/?currentTimeframe $=0 \&$ sortModel $=\% 7 \mathrm{~B} \%$ 22colId\%22:\%22Location\%22,\%22ssor\%22:\%22asc\%22\%7D (last visited Aug. 12, 2018).

21. Hefei Wen et al., Impact of Medicaid Expansion on Medicaid-Covered Utilization of Buprenorphine for Opioid Use Disorder Treatment, 55 MED. CARE 336, 338 (2017). But see Colleen Grogan et al., Survey Highlights Differences in Medicaid Coverage for Substance Abuse Treatment and Opioid Use Disorder Medications, 35 HEALTH AFF. 2289, 2292 (2016) (finding that while all states - even non-expansion states - covered medication-assisted therapy for substance abuse treatment, only twenty-six states and the District of Columbia covered some array of inpatient and/or outpatient treatment services). Moreover, the states that cover such treatment did not always overlap with those that expanded Medicaid. See id.

22. See, e.g., Office of the Assistant Sec'y for Planning \& Evaluation, Medicaid Expansion Impacts on Insurance Coverage and Access to Care, DEP'T HEALTH \& HuM. SERvs. 8 (2017), https://aspe.hhs.gov/system/files/pdf/255516/medicaidexpansion.pdf.

23. Tarek Mikati et al, The Change in Insurance Status Among Patients Seeking Care at Chicago Sexually Transmitted Disease Clinics After Affordable Care Act Implementation, 43 SeXUally TRANSmitTEd Diseases 260, 260-61 (2016); Christie Mettenbrink et al, Assessing the Changing Landscape of Sexual Health Clinical Service After the Implementation of the Affordable Care Act, 42 SEXuAlly TRANSMITTED DISEASES 725, 726 (2015).

24. See, e.g., Robin Rudowitz \& Rachel Garfield, 10 Things About Medicaid: Setting the Facts Straight, KAISER FAM. FOUND. 4-5 (2018), http:/files.kff.org/attachment/Issue-Brief-10-Thingsto-Know-about-Medicaid-Setting-the-Facts-Straight (noting that $43 \%$ of all children in the United States are covered by Medicaid, and that Medicaid covers comprehensive benefits for children through the Early and Periodic Screening, Diagnosis, and Treatment (EPSDT) program). 
need less medical care than their peers who were uninsured in childhood. ${ }^{25}$ Earlier Medicaid expansions have been associated with significant reductions in all-cause mortality, ${ }^{26}$ and both earlier expansions and the ACA Medicaid expansion are associated with statistically significant declines in uninsurance and care delayed because of cost, and in improvements in self-reported health status. $^{27}$

Medicaid has been associated with increased screening and treatment for chronic health conditions. ${ }^{28}$ Overall, it plays a major role in providing people with the public health services and other care they need, ensuring they can get it without suffering undue financial distress. ${ }^{29}$ This last point-the role of Medicaid in providing financial and emotional peace of mind to beneficiariesmay perhaps be the most important. While there have been some conflicting results, ${ }^{30}$ a number of studies have found that the mere fact of having Medicaid coverage has improved beneficiaries' mental health and stress levels. ${ }^{31}$ Several studies have found that, following Medicaid expansion, qualifying adults in expansion states not only became more likely to be insured, but they also had

25. Laura R. Wherry et al., Childhood Medicaid Coverage and Later-Life Health Care Utilization, 100 Rev. ECON. \& STAT. 287, 300 (2018). See also Michel H. Boudreaux et al., The Long-Term Impacts of Medicaid Exposure in Early Childhood: Evidence From the Program's Origin, 45 J. HEALTH ECON. 161, 162 (2016); Laura R. Wherry \& Bruce D. Meyer, Saving Teens: Using a Policy Discontinuity to Estimate the Effects of Medicaid Eligibility, 51 J. HUM. RESOURCES 556,559 (2016).

26. Benjamin D. Sommers et al., Mortality and Access to Care Among Adults After State Medicaid Expansions, 367 NEW ENG. J. MED. 1025, 1026 (2012).

27. Id. at 1028-29; Katherine Baicker et al., The Oregon Experiment-Effects of Medicaid on Clinical Outcomes, 368 NEw ENG. J. MED. 1713, 1717-18 (2013).

28. Benjamin D. Sommers et al., Changes in Utilization and Health Among Low-Income Adults After Medicaid Expansion or Expanded Private Insurance, 176 JAMA INTERNAL MED. 1501, 1505 (2016).

29. Id. at 1501

30. See e.g., Laura Wherry \& Sarah Miller, Early Coverage, Access, Utilization, and Health Effects Associated With the Affordable Care Act Medicaid Expansions, 164 ANNALS INTERNAL MED. 795, 798-801 (2016).

31. See, e.g., Amy Finkelstein et al., The Oregon Health Insurance Experiment: Evidence from the First Year, 127 Q. J. ECON. 1057, 1061, 1095 (2012) (finding that Oregonians who received Medicaid through a state lottery were $10 \%$ more likely to screen negative for depression than the control mean, and about $25 \%$ more likely to report good, very good, or excellent health than the control mean); Baicker et al., supra note 27, at 1713, 1717 (finding a nearly $8 \%$ improvement in health-related quality of life and happiness among Oregonians who received Medicaid through a state lottery as compared to the control mean); Sommers et al., supra note 26, at 1025 (finding a 3.4\% increase in the rate of "excellent" or "very good" self-reported health among individuals gaining coverage through a state Medicaid expansion as compared to similar individuals in non-expansion states); Sommers et al., supra note 28, at 1501, 1505 (finding that the share of expansion adults reporting "fair" or "poor" health declined $7.1 \%$, and the share of expansion adults reporting "excellent" health increased $4.8 \%$ in the studied expansion versus nonexpansion states). 
better self-reported health and reduced levels of depression as compared to similarly-situated individuals in non-expansion states or to whom coverage was not extended. ${ }^{32}$ This correlates with findings from studies examining the impact of having health insurance coverage, generally, on the stress levels of previously uninsured individuals. ${ }^{33}$ Who would have thought all those insurance commercials could be correct: having secure, stable coverage can indeed be conducive to well-being and peace of mind. ${ }^{34}$

\section{Changes Sought by the Trump Administration}

Attempts by the Trump administration to weaken Medicaid coverage appear incongruous and unwarranted in light of the substantial public and population health benefits of Medicaid discussed above. Curiously-or perhaps not so curiously, given statutory requirements-the Trump administration seeks to justify its proposed changes by appealing to their alleged health benefits. One must wonder, what could these alleged health benefits possibly be to outweigh the extensive benefits conferred by Medicaid?

\section{A. Medicaid Work Requirements}

One way the Trump administration seeks to weaken Medicaid is through permitting interested states to institute certain requirements resembling those in place in welfare programs such as Temporary Assistance for Needy Families (TANF) and Supplemental Nutrition Assistance Program (SNAP). ${ }^{35}$ Medicaid does not offer cash or food or shelter, but rather it provides health services to qualifying, sometimes disabled or frail low-income Americans, and as such, fits poorly under the traditional "welfare" rubric. ${ }^{36}$ Moreover, it was, as originally conceived, offered only to the "deserving" poor-those who lacked means

32. See Sommers, supra note 28 , at $1502-05$; Finkelstein et al., supra note 31 , at 1095; Benjamin D. Sommers et al., Three-Year Impacts of the Affordable Care Act: Improved Medical Care and Health Among Low-Income Adults, 36 HEALTH AFF. 1119, 1119 (2017).

33. Benjamin D. Sommers et al., Health Insurance Coverage and Health-What the Recent Evidence Tells Us, 377 NEW ENG. J. MED. 586, 590-91 (2017).

34. Id. (It may additionally not matter whether the coverage is Medicaid or private.).

35. See Jared Bernstein \& Hannah Katch, Trump Administration's Under-the-Radar Attack on Medicaid is Picking Up Speed, WASH. PoST (Mar. 6, 2018), https://www.washingtonpost.com/ news/posteverything/wp/2018/03/06/trump-administrations-under-the-radar-attack-on-medicaidis-picking-up-speed/?noredirect=on\&utm_term=.e9f0ed433031; see also Ctrs. for Medicare \& Medicaid Servs., RE: Opportunities to Promote Work and Community Engagement Among Medicaid Beneficiaries (Jan. 11, 2018), https://www.medicaid.gov/federal-policy-guidance/down loads/smd18002.pdf; Teresa Coughlin \& Stephen Zuckerman, State Responses to New Flexibility in Medicaid, 86 MILBANK Q. 209, 209-10 (2008).

36. See Gary Smith et al., Office of the Assistant Sec'y for Planning \& Evaluation, Understanding Medicaid Home ANd Community Services: A PRIMER 58 (2000). 
because they were disabled, elderly, or without a spouse. ${ }^{37}$ But as access to Medicaid expanded, certain groups have increasingly sought to institute personal responsibility requirements in the program such as time limits, work mandates, and lockouts for non-compliance. ${ }^{38}$ In keeping with this end, the Trump administration has started encouraging interested states to "consider aligning Medicaid requirements with certain aspects of the TANF or SNAP programs." 39

The proposed congruence is not intended to improve or simplify administration of the different programs ${ }^{40}$ Rather, it is intended to move nondisabled, non-elderly adults off the Medicaid rolls. ${ }^{41}$ Most adults who could be subject to work requirements under current proposals are already employed. ${ }^{42}$ While some may leave the rolls because they are lucky enough to find a job that

37. Robert Stevens \& Rosemary Stevens, Welfare Medicine in America: A Case STUDY OF MEDICAID 8 (Taylor \& Francis Group, revised ed. 2003).

38. See, e.g., Laura D. Hermer, On the Expansion of "Welfare" and "Health" under Medicaid, 9 ST. LouIS U. J. HEALTH L. \& POL'Y 235, 241, 250-57 (2016) (noting more recent features of ACA Medicaid expansions using $§ 1115$ waivers).

39. Ctrs. for Medicare \& Medicaid Servs., supra note 35, at 4

40. See e.g., Julia B. Issacs et al., Changing Policies to Streamline Access to MEDICAD, SNAP, AND CHILD CARE ASSISTANCE 4 (2016) (summarizing the purposes for which states sought the grant); see also Work Support Strategies, CLASP, https://www.clasp.org/worksupport-strategies (last visited September 14, 2018) (offering private funding and technical assistance to states to streamline and better integrate work support programs such as health care, nutritional assistance, and child care, to make them easier to access and use.).

41. Seema Verma, Adm'r, Ctrs. for Medicare \& Medicaid Servs.: Remarks at the National Association of Medicaid Directors (NAMD) 2017 Fall Conference (Nov. 7, 2017) ("While many responded to [the ACA's Medicaid] expansion with celebration, we shouldn't just celebrate an increase in the rolls, or more Medicaid cards handed out. For this population, for able bodied adults, we should celebrate helping people move up, move on, and move out.").

42. See, e.g., Rachel Garfield, Robin Rudowitz, \& Anthony Damico, Understanding the Intersection of Medicaid and Work, KAISER FAM. FOUND. 2-3 (2018), http://files.kff.org/attach ment/Issue-Brief-Understanding-the-Intersection-of-Medicaid-and-Work (finding that $60 \%$ of non-elderly, non-disabled adult Medicaid beneficiaries work either full or part time, and that a sizeable minority either work for small firms with historically low offers of coverage, or in industries that typically do not offer coverage to employees). A report from the President's Council of Economic Advisors finds, to the contrary, that $60 \%$ of non-disabled, working-age Medicaid beneficiaries worked fewer than 20 hours per week, and that $53 \%$ reported no income. THE COUNCIL OF ECON. Advisors, EXEC. OfFICE OF THE PRESIDENT, EXPANDING Work REQUIREMENTS IN NON-CASH WELFARE PROGRAMS, 1, 17 (2018). This report, however, uses 2013 SIPP numbers, from before the start of the Medicaid expansion. $I d$. at 13 . This is relevant because, in most states prior to 2014, most non-disabled, non-elderly adults on the Medicaid rolls only qualified for Medicaid if they had very little, if any, official earned income. Medicaid: Changes under the Affordable Care Act, HEALTH REFORM TRACKER, http://www.healthreform tracker.org/medicaid-changes-under-the-affordable-care-act/ (last visited Aug. 19, 2018). See

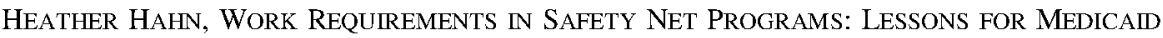
FROM TANF AND SNAP, 1, 4, 9 (2018) (finding that 58\% of households who are of working age and nondisabled are employed while receiving benefits) 
offers private coverage in response to a Medicaid work requirement, studies suggest that many others will be removed because of administrative complexity and confusion, ${ }^{43}$ inability to find a job, ${ }^{44}$ or frustration with the hassle involved in compliance. ${ }^{45}$

On January 11, 2018, CMS released a State Medicaid Directors (SMD) letter announcing that, contrary to all prior CMS policy, it would start "support[ing] state efforts to test incentives that make participation in work or other community engagement a requirement for continued Medicaid eligibility or coverage for certain adult Medicaid beneficiaries in [\$1115] demonstration projects ...."46 This comes as little surprise, as the current Administrator of CMS, Seema Verma, was a major proponent of "personal responsibility" requirements such as this prior to joining $\mathrm{CMS}^{47}$ By reducing the number of working-age adults on Medicaid, Verma intends to "restore" Medicaid to what she claims was the federal government's original intent for the program: "a partnership between the federal and state governments to care for society's most

43. See, e.g., Julia B. IsAacs, IMPROVIng THE EFFICIENCY OF BenEFIT Delivery: OUTCOMES FROM THE WORK SUPPORT STRATEgIES EVALUATION 38 (2018) ("Multiple recertification dates cause agencies to ask for and process the same-or at least similarinformation multiple times a year, creating duplicative work. Multiple redeterminations create confusion for families, who may be uncertain whether they have complied with requirements for all programs, and more opportunities for families to lose benefits.").

44. See, e.g., U.S. DEP'T OF AGRIC., EVALUATION OF SNAP EMPloymEnT AND Training PILOTS: FISCAL YEAR 2017 ANNUAL REPORT TO CONGRESS 8-9 (2017) (noting that SNAP participations in programs with mandatory work requirements tend to exit SNAP at much higher rates than those in voluntary work programs "mostly due to case closures for noncompliance," and observing that one of the mandatory pilot projects with a very short timeframe for compliance has seen more than 60 percent of participants exit the pilot project, in part due to disqualification for noncompliance).

45. See, e.g., Pamela Loprest et al., Welfare Reform Under PRWORA: Aid to Children with Working Families?, 14 TAX POL'Y ECON. 157, 192 (2000) ("The second most common reason for leaving, reported by 10 percent of leavers, was administrative problems or hassles.").

46. Ctrs. for Medicare \& Medicaid Servs., supra note 35 at 1.

47. See, e.g., Mitchell Roob \& Seema Verma, Indiana: Health Care Reform Amidst Colliding Values, HEALTH AFF. BLOG (May 1, 2008), https://www.healthaffairs.org/do/10.1377/hblog2008 0501.000383/full/ (writing that the Healthy Indiana Plan "is the first Medicaid expansion in the nation to be modeled in the spirit of a high deductible health plan (HDHP)/ health savings account (HSA). This structure melds two themes of American society that typically collide in our healthcare system, rugged individualism and the Judeo-Christian ethic. HIP combines these diametrically opposed themes by promoting personal responsibility while providing subsidized health protection to those who can least afford it."). Indiana, where Verma served as a health policy consultant under then-Governor Mike Pence, first sought to attach job training and employment services to Medicaid in 2015. HIP 2.0 SECTION 1115 Waiver ApPlication, Ind. FAM. \& SOC. SERVs. AdMin., 16 (2016) 
vulnerable citizens." 48 This curious pronouncement would evidently have the executive branch override current law to return to an antique form of Medicaid, even though any such authority is lacking.

CMS justified the change in policy, in part, on the alleged effect that "productive work and community engagement," among other factors, can have on health outcomes. ${ }^{49}$ In support of this proposition, it cites to several studies finding, for example, that wealthier people tend to live longer than those who are poor. ${ }^{50}$ It accordingly proposes that interested states apply for a Medicaid $\S 1115$ demonstration waiver "requir[ing] eligible adult beneficiaries to engage in work or community engagement activities (e.g., skills training, education, job search, caregiving, volunteer service) in order to determine whether those requirements assist beneficiaries in obtaining sustainable employment or other productive community engagement and whether sustained employment or other productive community engagement leads to improved health outcomes." 51

Section 1115 of the Social Security Act allows states to seek federal permission to not follow one or more federal rules regarding Medicaid in order to "test" how well a novel way of providing Medicaid benefits might work and still get federal Medicaid matching funds for it. ${ }^{52}$ To be granted, a demonstration proposal must meet a number of requirements, most notably including promotion of the objectives of the Medicaid statute. ${ }^{53}$ These objectives are found in 42 U.S.C. $\$ 1396-1$ :

For the purpose of enabling each State, as far as practicable under the conditions in such State, to furnish (1) medical assistance on behalf of families with dependent children and of aged, blind, or disabled individuals, whose income and resources are insufficient to meet the costs of necessary medical services, and (2) rehabilitation and other services to help such families and individuals attain or retain capability for independence or self-care, there is hereby authorized to be appropriated for each fiscal year a sum sufficient to carry out the purposes of this subchapter. ${ }^{54}$

This means that states seeking a Medicaid $\$ 1115$ waiver must demonstrate that their request will further either the provision of medical coverage or services, or the provision of rehabilitative services to relevant populations. ${ }^{55}$ Medicaid's statement of purpose nowhere reflects any objective that beneficiaries should

48. Verma, supra note 41; see also Thomas E. Price, Sec'y, Health \& Hum. Servs. and Seema Verma, Adm'r, Ctrs. for Medicare \& Medicaid Servs., Letter to State Governors (Mar.14, 2017), https://www.hhs.gov/sites/default/files/sec-price-admin-verma-Itr.pdf.

49. Ctrs. for Medicare \& Medicaid Servs., supra note 35, at 2.

50. Id.

51. $I d$.

52. See 42 U.S.C. § 1315(a) (Supp I. 2014).

53. See id.

54. 42 U.S.C. $\$ 1396-1$ (2012).

55. 42 U.S.C. $\$ 1396 d(a)$ (2012). 
strive to become self-supporting by obtaining jobs. ${ }^{56}$ If a state seeks a waiver that fails to further Medicaid's purpose, then the Secretary may deny it, ${ }^{57}$ or a court may find its grant to have been improper. ${ }^{58}$

56. See generally 42 U.S.C. $\$ 1315$ (2012); see also About Section 1115 Demonstrations, CTRS. FOR MEDICARE \& MEDICAID SERVS., https://www.medicaid.gov/medicaid/section-1115demo/about-1115/index.html (last visited Aug. 17, 2018). But cf. 42 U.S.C. § 601 (2012) (contrast Medicaid's statute with the purpose of TANF, which is to "(1) provide assistance to needy families so that children may be cared for in their own homes or in the homes of relatives; (2) end the dependence of needy parents on government benefits by promoting job preparation, work, and marriage; (3) prevent and reduce the incidence of out-of-wedlock pregnancies and establish annual numerical goals for preventing and reducing the incidence of these pregnancies; and (4) encourage the formation and maintenance of two-parent families.").

57. See, e.g., CTRS. FOR MEDICARE \& MEDICAID SERVS., 11-W-00275/09, ARIZONA HEALTH CARE COST CONTAINMEnT System (2016) ("Consistent with Medicaid law, CMS reviews $\S 1115$ demonstration applications to determine whether they further the objectives of the program, such as by strengthening coverage or health outcomes for low-income individuals in the state or increasing access to providers. After reviewing Arizona's application to determine whether it meets these standards, CMS is unable to approve the following requests, which could undermine access to care and do not support the objectives of the program: monthly contributions for beneficiaries in the new adult group with incomes up to and including 100 percent of FPL; exclusion from coverage for a period of six months for nonpayment of monthly premium contributions; a work requirement; fees for missed appointments; additional verification requirements; and a time limit on coverage."), https://www.medicaid.gov/MedicaidCHIPProgramInformation/ByTopics/Waivers/1115/down loads/az/Health-Care-Cost-Containment-System/az-hccc-demo-ext-09302016.pdf; see also CTRS. FOR Medicare and Medicaid Servs., Medicaid Low-Income Adult Coverage DEMONSTRATION (2013) (denying Connecticut's waiver request, finding that the proposal to impose an asset limit on very low-income beneficiaries would not likely to assist in promoting the objectives of title XIX), https://www.medicaid.gov/Medicaid-CHIP-Program-Information/ByTopics/Waivers/1115/downloads/ct/ct-medicaid-low-income-adults-coverage-ar.pdf.

58. Stewart v. Azar, 313 F. Supp. 3d 237, 261-62 (D.D.C. 2018) ("The fundamental failure here, however, is that [the Secretary] ignored [the] objective [of providing medical assistance] in evaluating Kentucky HEALTH. Instead, by his own description, the Secretary examined only the following factors in his consideration of KY HEALTH generally: (1) 'whether the demonstration was likely to assist in improving health outcomes'; (2) 'whether it would address behavioral and social factors that influence health outcomes'; (3) 'whether it would incentivize beneficiaries to engage in their own health care and achieve better health outcomes'; and (4) 'whether it would familiarize beneficiaries with a benefit design that is typical of what they may encounter in the commercial market and thereby facilitate smoother beneficiary transition to commercial coverage."'); Newton-Nations v. Betlach, 660 F.3d 370, 381-82 (9th Cir. 2011) (finding that " $[t]$ here is little, if any, evidence that the Secretary considered the factors $\S 1315$ requires her to consider before granting Arizona's waiver. Thus, the Secretary's decision was arbitrary and capricious within the meaning of the APA insofar as it "entirely failed to consider an important aspect of the problem."”); Wood v. Betlach, 922 F. Supp. 2d 836, 850-51 (D. Ariz. 2013) (finding that the Secretary's grant of Arizona's waiver request was arbitrary and capricious where the Secretary failed to consider evidence that imposition of higher copayments has resulted in beneficiaries relying on expensive emergency room care and having untreated conditions leading ultimately to more serious and expensive illnesses, rather than saving money that the state could then use to further Medicaid's purpose of providing coverage to certain low-income populations). 
CMS granted three state waiver applications in quick succession after issuing the January 11th letter: first Kentucky, ${ }^{59}$ then Indiana, ${ }^{60}$ and then Arkansas. ${ }^{61}$ In the case of Kentucky-the first waiver issued after the SMD letter-CMS spent an unusual amount of time justifying its decision, presumably in anticipation of the lawsuit which, indeed, soon followed. ${ }^{62}$ It claimed in the approval letter that work requirements might improve beneficiary health in two ways: by improving healthy behaviors and by diminishing reliance on public programs. ${ }^{63}$ Taken together, both appear to boil down to the following: independence is healthy. Independence is so healthy, in fact, that it is apparently unproblematic to restrict conditions of Medicaid eligibility for most non-

59. Demetrios L. Kouzoulas, Principal Deputy Adm'r, Ctrs. for Medicare \& Medicaid Servs., Letter to Stephen P. Miller, Comm'r, Ky. Cabinet for Health \& Family Servs. (Jan. 12, 2018), https://www.medicaid.gov/Medicaid-CHIP-Program-Information/By-Topics/Waivers/1115/down loads/ky/health/ky-health-cms-appvl-011218.pdf.

60. Demetrios L. Kouzoulas, Principal Deputy Adm'r, Ctrs. for Medicare \& Medicaid Servs., Letter to Allison Taylor, Medicaid Dir., Ind. Family \& Social Servs. Admin. (Feb. 1, 2018), https://www.medicaid.gov/Medicaid-CHIP-Program-Information/By-Topics/Waivers/1115/down loads/in/Healthy-Indiana-Plan-2/in-healthy-indiana-plan-support-20-ca.pdf.

61. Seema Verma, Adm'r, Ctrs. for Medicare \& Medicaid Servs., Letter to Cindy Gillespie, Dir., Ark. Dep't of Hum. Servs. (Mar. 5, 2018), https://www.medicaid.gov/Medicaid-CHIP-Pro gram-Information/By-Topics/Waivers/1115/downloads/ar/ar-works-ca.pdf. Since then, CMS has approved four other state work requirement waivers (Maine, Michigan, New Hampshire, and Wisconsin) and has deferred consideration of two other states' requests (North Carolina and Kansas). See Ctrs. For Medicare \& Medicaid SERvs., SPECIAl Terms and Conditions, $11-$ W-00322/1, MaineCare Section 1115 Demonstration 19-24 at 1, https://www.medicaid.gov/ Medicaid-CHIP-Program-Information/By-Topics/Waivers/1115/downloads/me/me-mainecare-

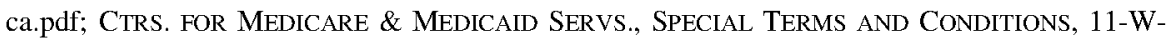
00245/5, Healthy Michigan Plan Section 1115 Demonstration 20-25 at 1, https://www.med icaid.gov/Medicaid-CHIP-Program-Information/By-Topics/Waivers/1115/downloads $/ \mathrm{mi} / \mathrm{mi}$ healthy-michigan-ca.pdf; CTRS. FOR MEDICARE \& MEDICAID SERvs., SPECIAL TERMS AND ConDiTions, 11-W-00298/1, New Hampshire Granite Advantage 10-19 at 1, https://www.medic aid.gov/Medicaid-CHIP-Program-Information/By-Topics/Waivers/1115/downloads/nh/nh-gran ite-advantage-health-care-program-ca.pdf; CTRS. FOR MEDICARE \& MEDICAID SERVS., SPECIAL TERMS AND CONDITIONS, 11-W-00293/5, Wisconsin BadgerCare Reform 9-14 at 1, https://www.medicaid.gov/Medicaid-CHIP-Program-Information/By-Topics/Waivers/1115/down loads/wi/wi-badgercare-reform-ca.pdf; Seema Verma, Adm'r, Ctrs. for Medicare \& Medicaid Servs., Letter to Dave Richard, Deputy Sec'y for Medical Servs., N.C. Dep't of Health \& Hum. Servs. 5-6 (Oct. 19, 2018), https://www.medicaid.gov/Medicaid-CHIP-Program-Information/ByTopics/Waivers/1115/downloads/nc/nc-medicaid-reform-ca.pdf; Mary Mayhew, Deputy Adm'r, Ctrs. for Medicare \& Medicaid Services, Letter to Jon Hamdorf, Medicaid Dir., Kansas Dep't of Health \& Env't (Dec. 18, 2018), https://www.medicaid.gov/Medicaid-CHIP-Program-Informa tion/By-Topics/Waivers/1115/downloads/ks/ks-kancare-ca.pdf.

62. See generally Stewart, 313 F. Supp. $3 d 237$ (D.D.C. 2018)

63. See Demetrios L. Kouzoulas, supra note 59, at 3-6. 
disabled, non-elderly adults and to remove coverage from non-compliant beneficiaries in order to make these individuals more independent. ${ }^{64}$

Some states are taking that concept and running with it, especially in the rhetoric they adopt. ${ }^{65}$ In its 2017 KanCare $\$ 1115$ Medicaid waiver extension application, Kansas, for example, discusses not only social determinants of health, but also "social determinants of independence." ${ }^{66}$ Recall the second purpose of Medicaid, enabling states to furnish "rehabilitation and other services to help such families and individuals attain or retain capability for independence or self-care . .." ${ }^{67}$ Both states and CMS know it is relatively unlikely that a court would find that removing Medicaid benefits from beneficiaries who fail to work at least eighty hours per month promotes the furnishing of medical assistance ${ }^{68}$ Hence, they are focusing on that second purpose, despite the fact that the purpose concerns helping people with disabilities to take care of themselves in the community and has nothing to do with weaning the ACA expansion population from public coverage.

Somehow, though-in addition to this first interpretive problem-the "rehabilitative or other services" piece has dropped out, leaving only the attainment of "capability for independence or self-care." ${ }^{69}$ Most of these waivers-including those already granted-make little if any provision for helping Medicaid beneficiaries search for jobs, get job training, and keep jobs by, for example, providing assistance with transportation and childcare. ${ }^{70}$ If any "rehabilitative or other services" exist, they typically are ones that already exist

64. See CTRS. For MediCARE \& MEdicaid SERVS., SPECIAL TERMS AND Conditions, No. 11-W-00306/4, KY HEALTH SECTION 1115 DEMONSTRATION 32-35 (2018). Kentucky estimated in its waiver application that 95,000 beneficiaries would lose coverage over the five-year waiver period as a result of the requirements sought in the waiver. COMMONWEALTH OF KENTUCKY, REQUEST FOR A SECTION 1115 DEMONSTRATION WAIVER FOR KENTUCKY HEALTH 72-73 (Aug. 24, 2016), https://www.medicaid.gov/Medicaid-CHIP-Program-Information/By-Topics/Waivers/ 1115/downloads/ky/ky-health-pa.pdf.

65. See generally Colleen M. Grogan et al., Rhetoric and Reform in Waiver States, $42 \mathbf{J}$. HEALTH POL. POL'Y \& L. 247, 248 (2017) (discussing the framing of personal responsibility in $\S 1115$ expansion waivers).

66. State of Kansas, KanCare 2.0 Section 1115 Demonstration Renewal APPLICATION 3 (Oct. 27, 2017), http://www.kancare.ks.gov/docs/default-source/about-kancare/ kancare-renewal-forums/kancare-renewal/kancare-2-0-waiver-renewal-application-for-publiccomment.pdf.

67. 42 U.S.C. $\S 1396-1$ (2012)

68. See Stewart v. Azar, 313 F. Supp. 3d 237, 243 (D.D.C. 2018).

69. 42 U.S.C. $\$ 1396-1$ (2012).

70. See, e.g., Anuj Gangopadhyaya et al., Medicaid Work ReQuirements in ARKANSAS: Who COULD BE AFFECTED, AND What Do WE KNOW ABOUT THEM? 5 (Urban Institute, 2018), https:/www.urban.org/sites/default/files/publication/98483/2001846_2018.05.23 _arkansas_medicaid_finalized.pdf (explaining how "states are not permitted to use any Medicaid funding to cover job training or education expenses, job search assistance, or support that could help enrollees obtain and retain jobs (e.g., child care, transportation.")) 
in connection with other programs rather than new ones proposed in connection with the $\S 1115$ waiver.

Kentucky's, Indiana's, and Arkansas's waivers fit this type. While additional activities such as education and job training count toward the twenty hours per week work requirement, the sole new assistance which Kentucky proposed to offer is coverage of out-of-pocket costs for taking the General Education Degree (GED) for beneficiaries who lack a high school diploma. ${ }^{71}$ Otherwise, and in addition to the prodigious administrative costs associated with keeping track of each beneficiary's compliance with the requirement, the state is only responsible to "[m]ake good faith efforts to connect Kentucky HEALTH beneficiaries to [already]-existing community supports."72 Indiana informs qualifying Medicaid beneficiaries of already-existing state job training and search programs. ${ }^{73}$ Arkansas does the same. ${ }^{74}$ Beneficiaries who fail to meet each state's documentation requirements will be dropped from the rolls. ${ }^{75}$

None of these demonstration projects, at least considered solely with reference to the work requirements they institute, should be considered to further Medicaid's purpose. ${ }^{76}$ All presume to diminish Medicaid coverage among affected beneficiaries. And none can reasonably be construed as offering "rehabilitative or other services" that might help beneficiaries attain or retain

71. COMMONWEALTH OF KENTUCKY, supra note 64 , at 46

72. CTRS. FOR MEDICARE \& MEDICAID SERVs., supra note 64, at 36.

73. InD. Fam. \& SOC. SERVS. AdMIN., AMENDMENT REQUEST to Healthy Indiana Plan (HIP) SECTION 1115 WAIVER EXTENSION APPLICATION 4 (July 20, 2017), https://www.medicaid. gov/Medicaid-CHIP-Program-Information/By-Topics/Waivers/1115/downloads/in/Healthy-Indi ana-Plan-2/in-healthy-indiana-plan-support-20-demo-app-07202017.pdf (discussing the "Gateway to Work" program); IND. FaM. \& Soc. SERvs. Admin., Healthy Indiana Plan (HIP) Section 1115 WAIVER EXTENSION APPLICATION, 17 (Jan. 31, 2017), https://www.medicaid.gov/MedicaidCHIP-Program-Information/By-Topics/Waivers/1115/downloads/in/Healthy-Indiana-Plan-2/inhealthy-indiana-plan-support-20-demo-app-02152017.pdf (noting that, while the Indiana Family and Social Services Administration sent 358,342 letters between May 2015 and August 2016 to HIP beneficiaries informing them of the existence of state job training and search programs, only 1,248 orientations were scheduled as a result, and only 580 ultimately attended one); CTRS. FOR MEDICARE \& MEDICAID SERVS., No. 11-W-00296/5, HEALTHy InDIANA Plan 18 (2018).

74. See CTRS. FOR MEDICARE \& MEDICAID SERVS., No. 11-W-00287/6, ARKANSAS WORKS 56 (2018)

75. Indiana beneficiaries who fail to document at the end of each year that they met the requirements for at least eight of the prior twelve months will be dropped from the rolls and, absent good cause, only reinstated after the the individual's eligibility redetermination date or after reactivating eligibility. See See Ctrs. FOR Medicare \& MediCAID SERvs., No. 11-W-00296/5, HEALTHY INDIANA PLAN 15 (2018). Arkansas beneficiaries who fail to certify eligibility for three months are dropped and are eligible to reapply only after the start of the next plan year. CTRS. FOR MEDICARE \& MEDICAID SERVS., No. 11-W-00287/6, ARKANSAS WORKS 24-25 (2018).

76. Stewart v. Azar, 313 F. Supp. 3d 237, 257 (D.D.C. 2018) (adopting the approach that the federal district court of Arizona took in Wood v. Betlach, and considering the waiver's effect as a whole, excluding the portion of the application concerning a separate substance use disorder treatment, rather than the effect of any individual component). 
self-care. It is implausible to think that a waiver that institutes Medicaid work requirements could possibly qualify as furthering the goals of Medicaid simply by bringing already-existing services to beneficiaries' attention by way of demanding that non-exempt beneficiaries work.

The one decision to date in a case challenging the legality of a $\$ 1115$ waiver imposing work and other personal responsibility requirements on beneficiaries hews carefully to both statutory requirements and well-established regulatory principles. ${ }^{77}$ Stewart $v$. Azar clearly stands for the proposition that $\$ 1115$ requires that waivers may be granted only where they further the purpose of Medicaid. ${ }^{78}$ A demonstration project that the State of Kentucky itself estimates will result in the loss of coverage for 95,000 individuals can hardly be said to likely assist in furthering Medicaid's goal of providing medical assistance to eligible state residents. ${ }^{79}$ The opinion deems irrelevant state claims that the waiver will improve independence or self-care by requiring non-exempt beneficiaries to work, pay increased premiums, lose retroactive eligibility and coverage of non-emergency medical transportation, be subject to increased reporting requirements, and get locked out from coverage for noncompliance. ${ }^{80}$ Medicaid § 1115 waivers are not about making beneficiaries less reliant on Medicaid or training them to use private coverage. Rather, they are intended to help eligible beneficiaries attain and retain medical assistance. ${ }^{81}$ The statutory language is not precatory. ${ }^{82}$ Otherwise, as the district court in Stewart noted, "what's to stop" the Secretary from using $§ 1115$ to "singlehandedly rewrite the Medicaid Act?" 83

What's more, it is difficult to imagine how the Secretary could possibly reach his original conclusion by more "adequately" considering Medicaid's purpose in deciding whether to grant the waiver. ${ }^{84}$ Yet, this is apparently what the Secretary had in mind at the time of this writing. In July 2018, he reopened the comment period on Kentucky's waiver application in light of the court's holding that the Secretary failed to adequately address the coverage loss issue in response to commenters' concerns. ${ }^{85}$ Given available research on the effects of

77. Id. at 244-45.

78. Id. at 260 .

79. Id. at 262,264 (finding that the Secretary failed to make any meaningful effect to ascertain how the project might help promote coverage).

80. Id. at 263-65.

81. Stewart, 313 F. Supp. 3d at 271-72.

82. See 42 U.S.C. $§ 1315$ (a) (2012).

83. Stewart, 313 F. Supp. 3d at 255.

84. Id. at 243.

85. See Kentucky HEALTH - Application and CMS STCs, CTRS. FOR MEDICAID \& MEDICARE SERVS., https://public.medicaid.gov/connect.ti/public.comments/viewQuestionnaire?qid=1897699 (last visited Aug. 16, 2018) ("In light of the district court's decision in Stewart v. Azar, No. 18-152 (D.D.C. June 29, 2018), we are inviting additional comments on Kentucky's demonstration project 
work requirements, ${ }^{86}$ increased premiums, ${ }^{87}$ and other waiver features, it would seem implausible that the Secretary could, even taking all the waiver features collectively, determine anything other than that the waiver will make it less likely that beneficiaries will be able to maintain medical assistance, let alone that the waiver will promote coverage. ${ }^{88}$ Yet the Secretary nevertheless reapproved the waiver. ${ }^{89}$ In response to commenters' objections that the demonstration, with its penalties for noncompliance with personal responsibility requirements and concordant, anticipated coverage losses, cannot advance Medicaid's purpose, CMS's Chief Principal Deputy Administrator responded that "the goal of these policies is to incentivize compliance, not reduce coverage." 90 In effect, the waiver's personal responsibility requirements are allegedly congruent with Medicaid's goals.

\section{B. Omission of Planned Parenthood from Medicaid Family Planning Services}

On a different note, family planning services are a required benefit in all Medicaid state plans. ${ }^{91}$ The ACA expanded access to family planning services

'Kentucky Helping to Engage and Achieve Long Term Health (KY HEALTH)' and its component parts, including the Kentucky HEALTH program.").

86. See, e.g., Work as a Condition of Medicaid Eligibility: Key Takeaways from TANF, MACPAC 4 (2017), https://www.macpac.gov/wp-content/uploads/2017/10/Work-as-a-Conditionof-Medicaid-Eligibility-Key-Take-Aways-from-TANF.pdf (discussing studies finding a significant decline in the TANF caseload following implementation of work requirements); Laura D. Hermer, What to Expect When You're Expecting...TANF-Style Medicaid Waivers, 27 ANNALS HEALTH L. 37, 66 (2018) (analyzing study of work requirements in TANF finding a reduction in "cash welfare use and payments").

87. See, e.g., Brendan Saloner et al., Medicaid and CHIP Premiums and Access to Care: A Systematic Review, 137 PEDIATRICS 1, 3 (March 2016) (finding in a meta-analysis of studies published between January 1995 and December 2014 that "premium increases are generally associated with reduced enrollment in premium insurance programs and decreases are associated with enrollment increases. Premiums that are more stringently enforced and premiums that are newly added (rather than increases of existing premiums) are associated with larger declines in enrollment.") (citations omitted).

88. See Stewart, 313 F. Supp. 3d at 262.

89. Paul Mango, Chief Principal Deputy Adm'r, Ctrs. for Medicare \& Medicaid Servs., Letter to Carol H. Steckel, Comm'r, Dep't for Medicaid Servs., Ky. Cabinet for Health \& Fam. Servs. 1 (Nov. 20, 2018), https://www.medicaid.gov/Medicaid-CHIP-Program-Information/By-Topics/ Waivers/1115/downloads/ky/ky-health-ca.pdf.

90. Id. at 12,14 (noting additionally that "... any loss of coverage as the result of noncompliance must be weighed against the benefits Kentucky hopes to achieve through the demonstration project, including both the improved health and independence of the beneficiaries who comply and the Commonwealth's enhanced ability to stretch its Medicaid resources and maintain the fiscal sustainability of the program").

91. See 42 U.S.C. \$ 1396d(a)(4)(C) (2012) ("The term "medical assistance' means payment of part or all of the cost of the following care and services or the care and services themselves, . . . [including] . . . family planning services and supplies furnished (directly or under arrangements 
in Medicaid by excluding such benefits from any cost-sharing requirement with respect to expansion populations and by allowing states, at their option, to create a new eligibility group, solely to receive family planning services, for people earning up to not more than the maximum set for Medicaid and Children's Health Insurance Program (CHIP) eligibility for pregnant women in the state. ${ }^{92}$ What's more, even though the vast majority of reproductive-age Medicaid beneficiaries are covered through managed care rather than on a fee-for-service basis, individuals in both managed care and "benchmark" coverage must have free choice of family planning service providers. ${ }^{93}$ While states may exclude family planning providers from Medicaid due to poor quality of care, provider qualification issues, or exclusion from public programs for fraud, abuse, or other convictions, their ability to do so on other grounds is largely curtailed. ${ }^{94}$ This is particularly important when it comes to providers like Planned Parenthood, which serves many Medicaid and other publicly-funded clients.

Nevertheless, some states have sought with increasing regularity to exclude providers like Planned Parenthood from Medicaid reimbursement. ${ }^{95}$ Planned Parenthood is a particularly important provider of reproductive health and other medical services for female Medicaid beneficiaries. In 2014, out of the sixtyseven million American women of reproductive age, thirty-eight million were sexually active and were neither pregnant nor trying to become pregnant. ${ }^{96}$ Of those thirty-eight million sexually active women, approximately half of them likely qualified for publicly funded care on the basis of either income or age. ${ }^{97}$ Medicaid funds the vast majority (seventy-five percent) of such care. ${ }^{98}$ Thirtysix percent of women of reproductive age with Medicaid rely on Planned Parenthood for their care, and over sixty percent of Planned Parenthood's

with others) to individuals of child-bearing age (including minors who can be considered to be sexually active) who are eligible under the State plan and who desire such services and supplies. ....").

92. 42 U.S.C. § 1396a(a)(10)(A)(ii)(XXI) (2012); § 1396a(ii); § 1396d(a)(4)(C).

93. 42 U.S.C. § 1396a(a)(23); § 1396u-7(b)(7); § 1396d(a)(4)(C); see also 42 C.F.R. \& 431.51(b)(2) (2018) ("A recipient enrolled in a primary care case-management system, a Medicaid $\mathrm{MCO}$, or other similar entity will not be restricted in freedom of choice of providers of family planning services.").

94. See 42 U.S.C. \$ 1396a(a)(23) (2012); see also Planned Parenthood of Kansas v. Andersen, 882 F.3d 1205, 1230 (10th Cir. 2018) ("All agree that states have considerable discretion in establishing provider qualifications .... But that authority entitles Kansas to set qualifications only for professional competency and patient care.").

95. Kinsey Hasstedt, Recent Funding Restrictions on the U.S. Family Planning Safety Net May Foreshadow What is to Come, 19 GUTTMACHER POL'Y REV. 67, 68 (2016).

96. Guttmacher Inst., Publicly Funded Family Planning Services in the United STATES 1 (2016), https://www.guttmacher.org/sites/default/files/factsheet/fb_contraceptive_serv _.pdf.

97. Id.

98. Id. Title $\mathrm{X}$ and state appropriations account for $10 \%$ and $12 \%$ of the remaining publicly funded share. $I d$. 
patients are funded by Medicaid or another public program. ${ }^{99}$ In sixty-eight percent of the 491 counties with a Planned Parenthood clinic, at least half the women who receive publicly funded contraceptive services received their services from Planned Parenthood. ${ }^{100}$ In twenty-one percent of those counties, Planned Parenthood was the sole provider of such services. ${ }^{101}$ In many cases, excluding state Planned Parenthood affiliates from Medicaid would eliminate a major source of reproductive health care for a substantial percentage of the state's Medicaid patients.

Referencing state attempts to exclude Planned Parenthood as a Medicaid provider, CMS wrote guidance in 2016 to State Medicaid Directors, stating that:

[b]ecause the "free choice of provider" provision guarantees Medicaid beneficiaries the right to see any willing and "qualified" provider of their choice, this provision limits a state's authority to establish qualification standards, or take certain actions against a provider, unless those standards or actions are related to the fitness of the provider to perform covered medical services-i.e., its capability to perform the required services in a professionally competent, safe, legal, and ethical manner-or the ability of the provider to appropriately bill for those services. Such reasons may not include a desire to target a provider or set of providers for reasons unrelated to their fitness to perform covered services or the adequacy of their billing practices. ${ }^{102}$

According to this guidance, states may not seek to exclude providers such as Planned Parenthood because they offer abortions, among other services. Rather, providers may only be excluded if they are professionally unfit to render the health care services in question. ${ }^{103}$ The right of both beneficiaries and providers

99. Jennifer Frost \& Kinsey Hasstedt, Quantifying Planned Parenthood's Critical Roll in Meeting the Need for Publicly Supported Contraceptive Care, HEALth AFFAIRS BLOG (Sept. 8, 2015), https://www.healthaffairs.org/do/10.1377/hblog20150908.050394/full/; Miriam Berg, How Federal Funding Works at Planned Parenthood, PLANNEd PARENTHOOD ACTION Fund (Jan. 5, 2017), https://www.plannedparenthoodaction.org/blog/how-federal-funding-works-at-plannedparenthood.

100. Frost \& Hasstedt, supra note 99.

101. Id.

102. Vikki Wachino, Dir., Ctrs. for Medicare \& Medicaid Servs., Letter Clarifying "Free Choice of Provider" Requirement in Conjunction with State Authority to Take Action Against Medicaid Providers (Apr. 19, 2016), https://www.medicaid.gov/federal-policy-guidance/down loads/smd1600s.pdf.

103. See, e.g., Planned Parenthood Arizona Inc. v. Betlach, 727 F.3d 960, 969 (9th Cir. 2013) (". . . the term 'qualified' is not specially defined within the Medicaid Act. We therefore read that term, as it appears in $\S 1396 a(a)(23)$, as conveying its ordinary meaning, which is: 'having an officially recognized qualification to practice as a member of a particular profession; fit, competent' .... [W]ere there any doubt as to how we should read the word "qualified" in $\S 1396 a(a)(23)$, Congress removed it by adding the further specification "qualified to perform the service or services required.' 42 U.S.C. $\$ 1396 \mathrm{a}(\mathrm{a})(23)$ (A) (emphasis added). ... Here, the words 'to perform the service or services required' modify the adjective 'qualified,' telling us that Congress meant for that adjective not to refer to a Medicaid Act-specific authorization, but to denote the capability to 
such as Planned Parenthood to enforce this provision under $\S 1983$ has been upheld in five out of six circuits, to date. ${ }^{104}$

Nevertheless, in 2018, Trump's CMS rescinded the 2016 guidance. CMS claimed, without offering any explanation or further discussion, that the 2016 guidance "raises legal issues under the Administrative Procedure Act, and limited states' flexibility with regard to establishing reasonable Medicaid provider qualification standards." 105 It directed states instead to "continue to look to Section 1902(a)(23) and our regulations at 42 C.F.R. $\S 431.51$ to determine their obligations under Section 1902(a)(23)." 106

Some recent cases may provide some illumination to the Trump administration's action. In 2015, an anti-abortion group released heavily edited and now discredited videos ${ }^{107}$ purporting to demonstrate that Planned Parenthood profits from the sale of tissue from aborted fetuses. ${ }^{108}$ Alabama, Arkansas, Kansas, Louisiana, Texas, and Utah responded to the videos by seeking to terminate their Medicaid provider agreements with Planned Parenthood, citing Planned Parenthood's allegedly unethical conduct. ${ }^{109}$ In all

carry out a particular activity - 'perform[ing] the [medical] service' that a given Medicaid recipient requires."); see also Planned Parenthood of Kansas v. Andersen, 882 F.3d 1205, 1230 (10th Cir. 2018)

104. See Andersen, 882 F.3d at 1248; Betlach, 727 F.3d at 975; Planned Parenthood of Gulf Coast, Inc. v. Gee, 862 F.3d 445, 457 (5th Cir. 2017); Planned Parenthood of Indiana, Inc. v. Commissioner of Indiana State Dep't of Health, 699 F.3d 962, 978 (7th Cir. 2012); Harris v. Olszewski, 442 F.3d 456, 461-62 (6th Cir. 2006); but see Does v. Gillespie, 867 F.3d 1034, 1046 (8th Cir. 2017) (finding that $\$ 1396 a(a)(23)$ does not unambiguously create a federal right enforceable under $§ 1983$ ).

105. Wachino, supra note 102 .

106. Id.

107. See Jackie Calmes, Planned Parenthood Videos Were Altered, Analysis Finds, N. Y. TIMES, Aug. 27, 2015.

108. Id.

109. See Planned Parenthood Southeast, Inc. v. Bentley, 141 F.Supp.3d 1207, 1212 (M.D. Ala. 2015) (noting that, although " $[\mathrm{t}]$ he letter did not provide a reason for the termination and advised PPSE that the termination would go into effect 15 days later[,] [t]he Governor state[ed] in his briefing in this court that his decision to terminate was based on his viewing one of the videos released by the Center for Medical Progress"); John Selig, Director, Arkansas Dep't of Hum. Servs., Letter to Jill June, President and CEO, Planned Parenthood of Arkansas and Eastern Oklahoma (August 14, 2015), https://www.arktimes.com/media/pdf/letter_from_dhs.pdf; Jason Osterhaus, Program Integrity Unit Manager, Kansas Dep't of Health \& Env't, Letter to Planned Parenthood of Mid Miss [sic] (May 3, 2016), http://mediad.publicbroadcasting.net/p/kcur/files/ kdhe_termination_letter.pdf?_ga=1.21266873.32030369.1453836694; Planned Parenthood Gulf Coast, Inc. v. Kliebert, 141 F.Supp.3d 604, 614-15 (M.D.La. 2015) (discussing Gov. Jindal's termination letter to Planned Parenthood); Planned Parenthood of Greater Tex. Family Planning \& Preventive Health Serv. v. Smith, 236 F.Supp.3d 974, 986 (W.D.Tex. 2017) (noting that the Texas Dep't of Health and Human Services Commission's termination letter to the state's Planned Parenthood affiliates cited the videos as evidence of alleged unprofessional conduct); Planned Parenthood Ass'n of Utah v. Herbert, 828 F.3d 1245, 1250 (10th Cir. 2016) (quoting from Governor 
cases, the state's Planned Parenthood affiliate and/or Planned Parenthood patients brought suit to enjoin the termination. ${ }^{110}$ All such suits were successful in reversing the terminations as violations of Medicaid's free choice of provider statute, except one, at least at the date of this writing: Does $v$. Gillespie. ${ }^{111} \mathrm{In}$ reviewing the district court's grant of a temporary restraining order against Planned Parenthood's termination, the Eighth Circuit held that \$ 1396a(a)(23) does not confer an enforceable federal right sufficient to ground the plaintiffs' $\$ 1983$ claim, and hence that the plaintiffs were not likely to succeed on the merits of their free choice of provider claim. ${ }^{112}$ Other circuits have come to an opposite conclusion, finding instead that the clear language of $\$ 1396 \mathrm{a}(\mathrm{a})(23)$ confers an unambiguous and enforceable right to Medicaid-eligible patients to obtain services from the provider of their choice. ${ }^{113}$ The Eighth Circuit, however, instead analogized to the Supreme Court plurality's reasoning in Armstrong v. Exceptional Child Center, Inc ${ }^{114}$ finding, inter alia, that "a statute phrased as a directive to a federal agency typically does not confer enforceable

Herbert's directive to the Utah Dep't of Health that "In light of ongoing concerns about [Planned Parenthood of Utah], I have instructed state agencies to cease acting as an intermediary for passthrough federal funds to Planned Parenthood").

110. See, e.g., Planned Parenthood Arizona Inc. v. Betlach, 727 F.3d 960, 960 (9th Cir. 2013); Planned Parenthood of Kansas v. Andersen, 882 F.3d 1205, 1205 (10th Cir. 2018), cert. denied, 586 U.S. _ (2018); Planned Parenthood of Gulf Coast, Inc. v. Gee, 862 F.3d 445, 445 (5th Cir. 2017), cert. denied, 586 U.S. (2018); Planned Parenthood of Ind. v. Comm'r of the Ind. State Dept. of Health, 699 F.3d 962, 962 (7th Cir. 2012).

111. Does v. Gillispie, 867 F.3d 1034, 1046 (8th Cir. 2017).

112. Id. at 1041 .

113. See Harris v. Olszewski, 442 F.3d 456, 461 (6th Cir. 2006) ("First, in giving 'any individual eligible for medical assistance' a free choice over the provider of that assistance, the statute uses the kind of 'individually focused terminology' that 'unambiguously confer[s]' an 'individual entitlement' under the law....Second, in giving 'any individual eligible for medical assistance' a free choice over the provider of that assistance, the statute uses the kind of 'individually focused terminology' that 'unambiguously confer[s]' an 'individual entitlement' under the law....Third, the 'must ... provide' language of the provision confirms that the statute is "couched in mandatory, rather than precatory, terms"') (citations omitted); Planned Parenthood Ariz. Inc. v. Betlach, 727 F.3d 960, 966-67 (9th Cir. 2013) (finding that Congress created a clear and unambiguous right for individual Medicaid beneficiaries to have a free choice of provider, with objective and concrete standards for enforcement); Planned Parenthood of Kan. v. Andersen, 882 F.3d 1205,1226 (10th Cir. 2018) ("Congress has therefore clearly intended to grant a specific class of beneficiaries-Medicaid-eligible patients - an enforceable right to obtain medical services from the qualified provider of their choice"); Planned Parenthood of Gulf Coast, Inc. v. Gee, 862 F.3d 445, 459-60 (5th Cir. 2017) (reinforcing that 42 U.S.C. $\$ 1396 a(a)(23)$ creates a private right of action); Planned Parenthood v. Comm'r of Dept. of Ind. State Health, 699 F.3d 962, 974 (7th Cir. 2012) (agreeing with the district court that the free-choice-of-provider statute unambiguously gives Medicaid-eligible patients an individual right).

114. Armstrong v. Exceptional Child Center, Inc., 135 U.S. 1378, 1381 (2015). 
federal rights on the individuals," and that Congress gave enforcement authority to the Secretary of Health and Human Services. ${ }^{115}$

The Gillespie plaintiffs unsuccessfully sought temporary relief on other grounds in the district court rather than appealing the Eighth Circuit's order. ${ }^{116}$ Meanwhile, the defendants in both Gee and Andersen petitioned for certiorari, which the Supreme Court denied. ${ }^{117}$ If certiorari had been granted and if the petitioners had been successful in arguing that, using either Armstrong or O'Bannon v. Town Court Nursing Center, ${ }^{118}$ the language of $\S 1396 \mathrm{a}(\mathrm{a})(23)$ provides plaintiff patients no enforceable right to freedom of choice of providers, ${ }^{119}$ then states would have gained newfound effective leeway to exclude providers from Medicaid for reasons extraneous to professional competence and billing practices. While Planned Parenthood could appeal such decisions through administrative review, it would lack the ability to obtain a stay of the exclusion during the potentially lengthy process. Providers such as Planned Parenthood-ones that provide a full range of reproductive health services, including abortion - could find themselves faced in certain states with a choice between a potentially lengthy exclusion from Medicaid or eliminating abortion and possibly some forms of contraception from its menu of health services. ${ }^{120}$

If Planned Parenthood did lose Medicaid funding, we have some idea of what might happen. Effective January 1, 2013, Texas opted to fund its public family planning program entirely with state funds so it could avoid having to

115. Does v. Gillespie, 867 F.3d 1034, 1041 (8th Cir. 2017)

116. See Preliminary Injunction Order at 1, Planned Parenthood of Ark. \& Eastern Okla. v. Gillespie, No. 4:15-cv-566-KGB (July 30,2018). At the time of this writing, the case is continuing in the district court on the merits.

117. Petition for Writ of Certiorari at 1, Andersen v. Planned Parenthood of Kan. and Mid-Mo., 882 F.3d 1205 (10th Cir. 2018) (No. 17-1340), https://www.supremecourt.gov/DocketPDF/17/171340/39617/20180321141128195_Andersen\%20v.\%20Planned\%20Parenthood\%20of\%20Kan sas\%20et\%20al._Petition.pdf; Petition for Writ of Certiorari at ii, Gee v. Planned Parenthood of Gulf Coast, Inc., 862 F.3d 445 (5th Cir. 2017) (No. 17-1492), https://www.supremecourt.gov/ DocketPDF/17/17-1492/44870/20180427135540119_Gee\%20v\%20Planned\%20Parenthood cert.\%20petition_PDF-a.pdf; Gee v. Planned Parenthood of Gulf Coast, Inc., 586 U.S. __ (2018); Planned Parenthood of Kansas v. Andersen, 882 F.3d 1205, 1205 (10th Cir. 2018), cert. denied, 586 U.S. (2018).

118. Armstrong v. Exceptional Child Center, Inc., 135 U.S. 1378, 1381 (2015); O'Bannon vs. Town Court Nursing Center, 447 U.S. 773, 773 (1980).

119. Subject only, that is, to professional and fraud-related considerations. See Wachino, supra note 102.

120. At the same time, CMS is proposing, at the time of this writing, to prohibit clinics that provide abortions among other reproductive health services from receiving Title X funding. See Compliance with Statutory Program Integrity Requirements, 83 Fed. Reg. 25,502, 25,531-32 (proposed Jun. 1, 2018) (to be codified at 42 C.F.R. pt. 59). 
include Planned Parenthood affiliates. ${ }^{121}$ Some studies have since examined the effects of this decision. A 2016 New England Journal of Medicine article found that, when comparing the two years preceding clinic exclusion to the two years following that exclusion, claims for long-acting, reversible contraceptives (LARCs) fell by over thirty-five percent in counties with Planned Parenthood affiliates. ${ }^{122}$ Claims for injectable contraceptives dropped by thirty-one percent. ${ }^{123}$ The percentage of women in counties with Planned Parenthood affiliates who renewed their contraception injection declined from fifty-seven percent to thirty-eight percent, and among that same group of women, the rate of childbirth covered by Medicaid increased 1.3 percentage points, from 7.0 percent to 8.4 percent. ${ }^{124} \mathrm{In}$ short, contraception decreased, and births increased.

Women's preventive health services suffered as well. As Planned Parenthood clinics shut, Texas women had to travel farther to access services. ${ }^{125}$ A 100-mile increase in driving distance to a clinic was associated with an eighteen percent reduction in clinical breast exams, seven percent reduction in receipt of a mammogram, and a fourteen percent drop in Pap testing rates. ${ }^{126}$ Nevertheless, Texas is currently seeking to reobtain federal Medicaid matching funds for its presently state-only funded Women's Health Program, with state law prohibiting funding for providers or affiliates of providers who offer abortion services intact. ${ }^{127}$

These outcomes are not merely harmful for the affected women and families. Rather, they also cost the state more money. Unplanned pregnancies are more likely to be covered by public funds than planned ones. For example, one study found that public programs paid for sixty-four percent of unintended births in

121. See Tex. Hum. Res. Code $\S 32.024$ (c-1) (2018) (providing that "The commission shall ensure that money spent for purposes of the demonstration project for women's health care services under former Section 32.0248 or a similar successor program is not used to perform or promote elective abortions, or to contract with entities that perform or promote elective abortions or affiliate with entities that perform or promote elective abortions."); see also Dep't of State Health Servs. v. Balquinta, 429 S.W.3d 726, 732-33 (Tex. App. 2014) (summarizing the course of events leading to Texas's decision).

122. Amanda J. Stevenson et al., Effect of Removal of Planned Parenthood from the Texas Women's Health Program, 374 NEW ENG. J. MED. 853, 858 (2016).

123. Id.

124. Id.

125. See Marissa Evans, Texas Wants to Renew Federal Women's Health Funding it Lost Over Planned Parenthood, TEX. TRIBUNE (May 16, 2017), https://www.texastribune.org/2017/05/16/ womens-health-programs-saw-sharp-decline-clients/.

126. Yao Lu \& David J. G. Slusky, The Impact of Women's Health Clinic Closures on Preventive Care, 8 AM. ECON. J. 110, 113-15 (2016) (providing rates for women with a high school diploma, GED, or less).

127. Texas Health \& Hum. Servs. Comm'n, Healthy Texas Women Section 1115 Demonstration Waiver Application 3 (Jun. 30, 2017), https://www.medicaid.gov/Medicaid-CHIPProgram-Information/By-Topics/Waivers/1115/downloads/tx/tx-healthy-women-pa.pdf; Tex. Hum. Res. Code § 32.024(c-1) (2018); see also Evans, supra note 125. 
2006 -costs amounting to over $\$ 6.5$ billion at the federal level and $\$ 4.6$ billion at the state level, for that year alone. ${ }^{128}$ In contrast, only thirty-five percent of planned pregnancies were covered by public programs. ${ }^{129}$ In 2010, public programs funded sixty-eight percent of unintended births, as compared to thirtyeight percent of intended ones. ${ }^{130}$ Costs increased to $\$ 14.6$ billion at the federal level and $\$ 6.4$ billion at the state level. ${ }^{131}$ These costs, however, encompass only prenatal care, labor and delivery, postpartum care, and sixty months of healthcare for the infant. ${ }^{132}$ When one considers additional public costs of caring for and educating the children, the costs become far greater. For example, one study focusing solely on the State of California found that the public savings from unintended births that were avoided in 2002 through one of the state's family planning waiver programs totaled over $\$ 2.2$ billion over the subsequent five years. ${ }^{133}$

\section{CONCLUSION}

When ideology trumps public health, it leads to bad results. But perhaps more dismaying is seeing how tenuous our rights can sometimes be under the Medicaid statute, and how quickly our policies can change from ones that favor improved public and population health outcomes through the expansion of public programs to ones that favor the elevation of personal responsibility rhetoric and anti-abortion ideology over public health.

Perhaps we are looking at the wrong outcomes for Medicaid. To better protect Medicaid and strengthen public support for it, it may make more sense to focus not on granular medical outcomes when evaluating Medicaid's success, but rather on the larger role it plays in supporting beneficiaries' lives. Rather than seeing if blood pressure or diabetes is better controlled or if beneficiaries are more likely than the chronically uninsured to receive earlier diagnoses with better outcomes, we should instead focus more strongly on how the program helps improve social, financial, and emotional resilience over time. The Trump administration is right that independence is healthy. However, it is difficult to

128. Adam Sonfield et al., The Public Costs of Births Resulting from Unintended Pregnancies: National and State-Level Estimates, 43 PERSPECTIVES ON SEXUAL \& REPROD. HEALTH 94, 97 (2011)

129. Id. at 97 .

130. AdAM SONFIELD \& KaTHERINE KOST, PUBLIC COSTS FROM UNINTENDED PREGNANCIES and the Role of Public Insurance Programs in PAying for PREgnancy-Related Care: NATIONAL AND STATE ESTIMATES FOR 20108 (2015), http://citeseerx.ist.psu.edu/viewdoc/down load?doi=10.1.1.700.5575\&rep=rep1\&type=pdf.

131. Id.

132. Id. at 4 .

133. Gorette Amaral et al., Public Savings from the Prevention of Unintended Pregnancy: A Cost Analysis of Family Planning Services in California, 42 HEALTH SERVS. RES. 1960, 1970 (2007). 
be independent if one lacks health, or faces financial ruin if one needs healthcare, or has unreasonable or nonexistent family planning and reproductive health choices. Evidence suggests that stable, secure access to coverage via Medicaid, as one piece of our safety net, makes beneficiaries feel more emotionally and financially secure and provides them improved access to needed services. ${ }^{134}$ As such, if Medicaid were allowed to remain both expansive and stable, we may reasonably expect gradually to see more stability in communities supported by Medicaid and other social supports, and more freedom of opportunity for beneficiaries and their families. Such a strategy would call the Trump administration on its own rhetoric while providing working-class Trump supporters with means to help attain their desired ends. It is a strategy worth trying. 


\title{
Mitchell Hamline Open Access
}

Mitchell Hamline Open Access is the digital archive of Mitchell Hamline School of Law. Its mission is to preserve and provide access to our scholarly activities, for the benefit of researchers and members of the legal community.

Mitchell Hamline Open Access is a service of the Warren E. Burger Library.

open.mitchellhamline.edu

\author{
$\mathrm{MH}$ \\ MITCHELL | HAMLINE \\ School of Law \\ (C) Mitchell Hamline School of Law \\ 875 Summit Avenue, Saint Paul, MN 55105 \\ mitchellhamline.edu
}

